\title{
Effect of Addition of Soursop Leaf Extract to Ganyong (Canna edulis Ker.) Starch Edible Film and its application in Red Grape Storage Time
}

\author{
Erni Widyastuti ${ }^{1}$, Endaruji Sedyadi ${ }^{2}$, Susy Yunita Prabawati ${ }^{3}$ \\ ${ }^{1,2,3}$ Chemistry Department, Faculty of Science and Technology, UIN Sunan Kalijaga, \\ J1. Marsda Adisucipto No 1 Yogyakarta 55281, Indonesia. Tel. +62-274-540971, Fax. +62-274-519739 \\ Author correspondency: \\ endaruji@yahoo.com ${ }^{2}$
}

\begin{abstract}
This study aimed to determine the effect of addition of Soursop leaf extract to edible film and its effect on the storage time of red grapes. This research had three main steps, soursop leaf extraction, edible film making, and application on red grapes storage time. Soursop leaves extract variation used in this research are $0.5 ; 1$; and $1.5 \%$ (w/w total) and the best result was used to coat the red grapes. The results showed that the optimum composition was obtained on the edible film with the addition of $0.5 \%$ (w/w total) soursop leaf extract. The composition increased film thickness from 0.03 to $0.08 \mathrm{~mm}$, decreased film's tensile strength from 11.89 to $8.42 \mathrm{MPa}$, decreased elongation from 12.71 to $11.03 \%$, decreased the Young Modulus from 0.935 to $0.764 \mathrm{MPa}$, and decreased the vapor transmission rate from 7.45 to $6.55 \mathrm{~g} / \mathrm{m}^{2}$.hour. The $50 \%$ shrinkage of weight and $50 \%$ texture damage are used as parameters to measure the Red grapes storage time. Based on weight shrinkage, red grapes storage time change from 24 days to 29 days by using an edible film coating without addition of extract, an extend to 32 days while using an edible film coating with addition of soursop leaf extract. Based on texture damage, red grapes storage time increased from 13 to 41 days if using an edible film coating without addition of extract, and increased to 40 days using an edible film coating with the addition of soursop leaf extract.
\end{abstract}

Keywords: Antioxidant; Edible Film; Soursop Leaf Extract; Aloe vera L.; Ganyong Starch.

\section{INTRODUCTION}

Indonesia is a tropical country where many tropical plants such as pineapple, grapes, mango, and citrus are cultivated. Grape is a fruit that very common in many occasion. The fruit has round shape with a sweet taste and thin-skinned. Grape is known to have many benefits as anti-cancer and contain A, B, C, and E Vitamins (Suwarto, 2010).

Grape plant is a seasonal crop with harvest 2-3 times per year. The plant in the harvest season yielding 10 tons fruit per hectare. The abundant supply of grape during this harvest season caused problems for the farmer, i.e., rotten grapes. It is caused by the storage time of grape only reaches 14 days at room temperature. It takes a given preservation method for the grape to last longer.

Some ways that can be done to extend the storage time of grape are by cooling, coating with wax, and coating with active packaging. The use of wax as a coating are not suggested due to negative effect on human health. The preservation technique using cooling process requires a greater cost. Therefore, in this research we will carried out an active packaging coating to extend the storage time of grape. One of the active packaging is edible film.

Edible film is a thin and continuous layer made of edible materials. Layers are formed to coat the food components (coating) or placed between food components (film). A layer acts as a barrier to mass transfer (e.g. moisture, oxygen, lipids, light and solutes). The coating may also serve as a carrier of groceries and additives, as well as to improve the handling of a food (Krochta \& Johnston, 1997).

The main components of edible film can be grouped into three categories, namely hydrocolloids, lipids, and composites (Donhowe, 1994). Some types of hydrocolloids that can be used as edible films are proteins (gelatin, casein, soy protein, corn protein, and wheat gluten) and carbohydrates (starch, alginate, pectin, Arabian gum, and other carbohydrate modifications), whereas the lipid used is wax, glycerol and fatty acids (Irianto et al., 2006).

According to Suryadi (2011), application of ganyong starch and glycerol as edible film on strawberries (Fragaria ananasa) can extend the term life of strawberry fruit at room temperature that has a storage time of 2 days longer. Kismaryanti (2007) explained that the application of Aloe vera $\mathrm{L}$. gel as an edible film can inhibit the deterioration of the quality of tomato fruit that is prolong the storage time up to 3 days at room temperature. This research conducted an application of edible film of ganyong starch and Aloe vera $\mathrm{L}$. which is expected to inhibit damage and prolong the storage time of grape at room temperature. 
Edible film as an active packaging can be a carrier of flavors, dyes, antimicrobial agents and antioxidants (Murdianto, 2005). Soursop leaves have chemical content such as alkaloids, flavonoids, carbohydrates, saponins, tannins, phytosterols, terpenoids, and proteins. Flavonoids in soursop leaves can serve as antioxidants, antimicrobials, anti virals, photosynthetic regulators, and growth regulators (Edeoga et al., 2005). Antioxidants are one of the additives that can protect the food from damage due to the reaction of fat or oil oxidation. Antioxidants can also extend storage time by protecting foods against oxidation-induced deterioration such as rancidity, discoloration and loss of nutritional value (Harikedua, 2012).

\section{MATERIALS AND METHODS}

\section{Materials}

The materials used in this study were ganyong starch obtained from UGM Agro Plaza, Aloe vera L. and soursop leaf from Ngampilan's Market of Yogyakarta, glycerol p.a., red grape obtained from UGM Mirota Campus, $96 \%$ ethanol, $\mathrm{NaCl}$, silica gel. The tools used for analysis were screw micrometers, Universal Testing Machine, FTIR, UV-Vis spectrophotometer, and Konica Minolta CR-400 Chromameter.

\section{Soursop Leaf Extraction}

Soursop leaf was washed thoroughly and dried. Dried soursop leaves then blend until yielding a fine powder. The sample extraction was done by maceration method (immersion). Soursop leaf powder weighed as much as $100 \mathrm{~g}$ then put into the macerator and added 10 parts solvent. The solvent used is $96 \%$ ethanol. The samples were soaked for 5 days and once a day the samples were stirred for homogenization. The macerated extract is separated by precipitation and filtration. It was repeated at least twice with the same type and amount of solvent. The macerated extract was collected, then evaporated with a vacuum evaporator at $55{ }^{\circ} \mathrm{C}$ to obtain a viscous extract (Rivai et al., 2013). Soursop leaf extract obtained then tested for its antioxidant activity using a DPPH method and its functional group using a FTIR instrument.

\section{Edible Film Preparation}

Edible film preparation was made by $3 \%$ of aloe vera gel, $6 \%$ of ganyong starch, and $15 \%$ glycerol (w/w total) of aloe vera gel. Starch weight was suspensioned by addition of $100 \mathrm{ml}$ distilled water. Further stirred and heated for 30 minutes at $70{ }^{\circ} \mathrm{C} \pm 5^{\circ} \mathrm{C}$ (Afriyah et al., 2015). The suspension was cooled while stirring and then added soursop leaf extract as much as $0.5 \%, 1 \%$ and $1.5 \%$ at $50{ }^{\circ} \mathrm{C}$ then cooled to $37{ }^{\circ} \mathrm{C} .25 \mathrm{ml}$ of suspension then cast onto a $13 \times 18 \mathrm{~cm}$ mica plastic. The suspension of the film was dried at room temperature for 48 hours to allow the edible film to dry and easily removed. Edible films produced were tested for chemical properties (FTIR) and their physical properties include: thickness, tensile strength, elongation, Young Modulus, and water vapor transmission rate (WVTR).

\section{Application to Red Grape}

The grape was cleaned with running water and then dried. Furthermore, red grape was dipped into 2 edible film solutions. First, its dipped in a solution of ganyong starch and Aloe vera L. without addition. Other grape was dipped in a solution of ganyong starch and Aloe vera $\mathrm{L}$. with addition of soursop leaves extract with best characteristic $(0.5 \%)$. Red grape was dipped in solution at $40{ }^{\circ} \mathrm{C}$ and aerated to dry. The grape that has been coated with edible film was stored at room temperature $\left(25-27^{\circ} \mathrm{C}\right)$ (Lathifa, 2013). Data collection was done on days $1,4,7,10$ and 13 respectively. Red grape samples were tested for weight loss, texture, and color. Red grape not coated with edible film used as a control.

\section{RESULTS AND DISCUSSION}

\section{Soursop Leaf Extraction}

The extraction done in this research yielded the thick extract as much as $10.23 \mathrm{~g}$ and the yield of $9.49 \%$. The extract of soursop leaf was then analyzed using FTIR spectrophotometer to know the functional groups contained in the extract and tested the antioxidant activity using DPPH method. FTIR analysis results (Figure 1) showed soursop leaf extract gave spectrum on wave number $3387 \mathrm{~cm}-1(\mathrm{OH}), 2924,09 \mathrm{~cm}-1(\mathrm{CH}$ aliphatic), 1735,93 ( $\mathrm{C}=\mathrm{O}), 1612,49 \mathrm{~cm}-1(\mathrm{C}=\mathrm{C})$, $1072.42 \mathrm{~cm}-1$ (CO). These functional groups are identical with flavonoid compounds such as $\mathrm{OH}, \mathrm{C}-\mathrm{H}$ aliphatic, $\mathrm{C}=\mathrm{O}, \mathrm{C}=\mathrm{C}$, and $\mathrm{C}-\mathrm{O}$ (Suteja et al., 2016) groups. The results of testing of antioxidant activity obtained IC50 value $86.11 \mathrm{ppm}$ and classified as having active antioxidant activity.

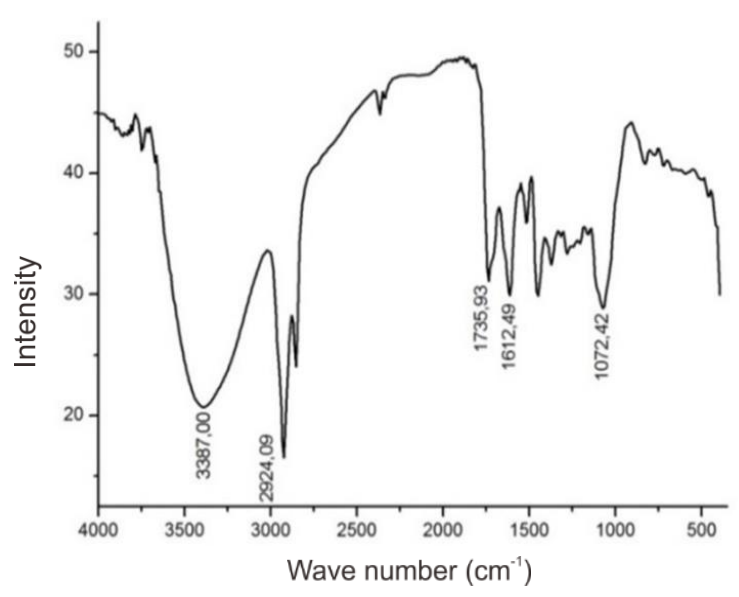

Figure 1. Spectrum of FTIR Test result of Soursop Leaf Extract. 


\section{Edible Film Making}

Ganyong and Aloe vera L. edible film without addition of soursop leaf extract have a thickness of $0.0325 \mathrm{~mm}$, tensile strength $11,89 \mathrm{MPa}$, elongation $12,71 \%$, Young modulus $0,935 \mathrm{MPa}$, and water vapor transmission rate $7,45 \mathrm{~g} / \mathrm{m}^{2}$ hour.

The thickness value of ganyong starch and Aloe vera L. edible films with the addition of soursop leaf extract ranged from 0,071-0,091 $\mathrm{mm}$ as shown in Table 1. It showed that the addition of soursop leaf extract effect the resulting film thickness. The greater concentration of the material causes the total amount of solids contained in the edible film to become larger, so that after the edible film suspension is drying the edible film obtained is thicker (Sulistiana and Widya, 2015).

Table 1 also shows that the tensile strength of ganyong and Aloe vera $\mathrm{L}$. edible films with the addition of soursop leaf extract ranged from 7,578-10,558 $\mathrm{MPa}$. The increased concentration of soursop leaf extract added will increase the tensile strength value of the edible film. It showed that the resulting edible film has a non-fragile nature. The results are similar to Murdianto's (2005) who studied the addition of janggelan leaf extract to the tapioca edible film. Addition the extract of janggelan leaves causing the increase of tensile strength of the resulting edible film. The addition of janggelan leaf extract to edible film causes more components available to bind to starch molecules, so the resulting edible film becomes more robust and requires greater tensile force to break edible film.

Table 1. Physical properties test result of Edible film Bulbs Ganyong and Aloe vera L. with the addition of Soursop Leaf Extract.

\begin{tabular}{lccc}
\hline \multirow{2}{*}{ Properties } & \multicolumn{3}{c}{$\begin{array}{c}\text { Concentrations of Soursoup } \\
\text { Leaf Extract }\end{array}$} \\
\cline { 2 - 4 } & $0,5 \%$ & $1 \%$ & $1,5 \%$ \\
\hline Thickness $(\mathrm{mm})$ & 0,088 & 0,091 & 0,071 \\
Tensile strength (MPa) & 8,424 & 7,578 & 10,558 \\
Elongation $(\%)$ & 11,033 & 8,719 & 6,867 \\
Modulus young & 0,764 & 0,869 & 1,538 \\
Water vapor transmission & 6,55 & 7,88 & 8,02 \\
rate $\left(\mathrm{g} / \mathrm{m}^{2}\right.$. hour $)$ & \multicolumn{3}{c}{} \\
\hline
\end{tabular}

Elongation of edible film decreased as the concentration of soursop leaf extract added. The same result are the study of edible corn starch film which was added black temu as antioxidant by Kusumawati \& Putri (2013) i.e. where the higher temu hitam added will reduce elongation. The presence of starch still bound to the temu hitam can increase the total solids that can strengthen the film matrix and reduce the elongation of the edible film.

Young modulus of ganyong starch and Aloe vera $\mathrm{L}$. edible film with the addition of soursop leaf extract ranged from $0.764-1.538 \mathrm{MPa}$. The increase in Young's Modulus shows the resulting edible film's declining flexibility (Nahwi, 2016). Based on Table 1, the highest Young Modulus score of 1,538 MPa showed edible film with addition of soursop leaf extract $1.5 \%$ (b/b total) more rigid compared with edible film with addition of soursop leaf extract $0,5 \%$ and $1 \%$.

The rate of water vapor transmission (WVTR) is the amount of moisture lost per unit time divided by the area of the plastic. Factors influencing the rate of water vapor transmission are thickness, plasticizer concentration, and type of plastic base material (Ekawati, 2015). The increased concentration of soursop leaf extract added will increase the value of water vapor transmission rate from edible film.

Addition of soursop leaf extract may reduce the hydrogen bonds in the intermolecular bond matrix and allow for the breaking of bonds between the amylose chains (Sari et al., 2013). Reduced amylose chains that make up the edible film will have an impact on the matrix of the film that has become less dense. The dense film matrix will be easily penetrated by water vapor (Santoso et al., 2011). According to Afriyah et al. (2015) the value of the vapor transmission rate of the edible film is influenced by $\mathrm{a}_{\mathrm{w}}, \mathrm{RH}$, temperature, type, edible film-forming properties and the arrangement of starch granules. Edible film with flour base tends to have a high rate of water vapor transmission rate.

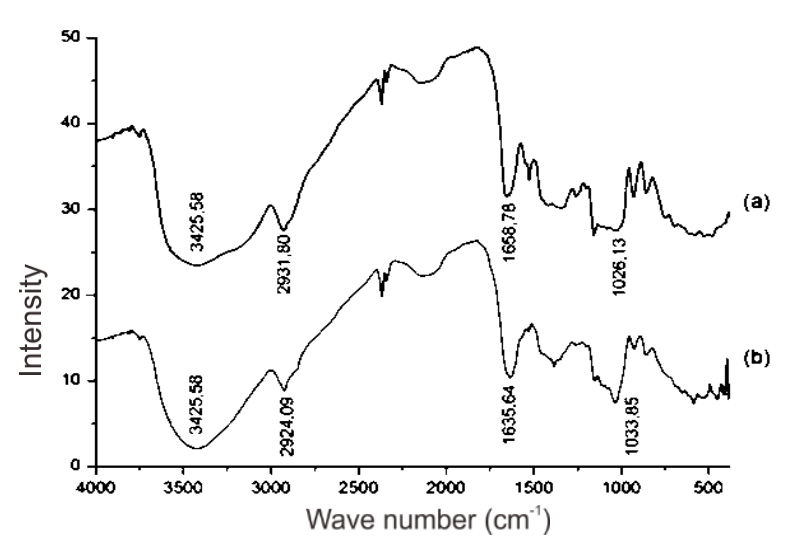

Figure 2. FTIR spectra of (a) Ganyong Starch and Aloe vera L. edible film without the addition of Soursop Leaf Extract and (b) with the addition of Soursop Leaf Extract.

FTIR spectra of ganyong and Aloe vera L. edible film without soursop leaf extract and with addition of soursop leaf extract are showed in Figure 2. Its yielded a wide absorption at 3425,58 indicating the vibration of $\mathrm{OH}$ group and some shift of wave number that is at $2931,80 \mathrm{~cm}^{-1}$ to $2924,09 \mathrm{~cm}^{-1}$ (CH stretching), 1658,78 $\mathrm{cm}^{-1}$ to $1635,64 \mathrm{~cm}^{-1}(\mathrm{C}=\mathrm{O})$, and $1026,13 \mathrm{~cm}^{-1}$ become $1033,85 \mathrm{~cm}^{-1}(\mathrm{CO})$.

\section{Application to Red Grape}

The percentage of red grape weight loss (Figure 3.) increases with the length of red grape storage. During 
storage, the shrinkage of fruit weight tends to increase and cannot be prevented. This is due to the physiological processes of respiration and transpiration during storage (Lathifa, 2013).

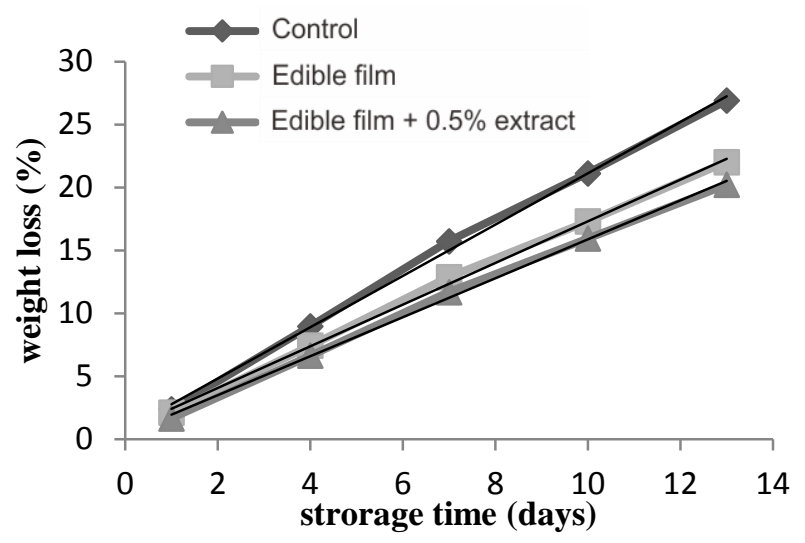

Figure 3. Graph of measurement results of Red Grape Wrap during storage.

Red grape storage time is determined based on red grape damage against losing weight of $50 \%$ using the equation of the line. Red grape loses $50 \%$ weight loss on 24th day on red grape control, 29th day on red grape coated with edible film without addition of extract, and day 32 on red grape coated edible film with addition of soursop leaf extract.

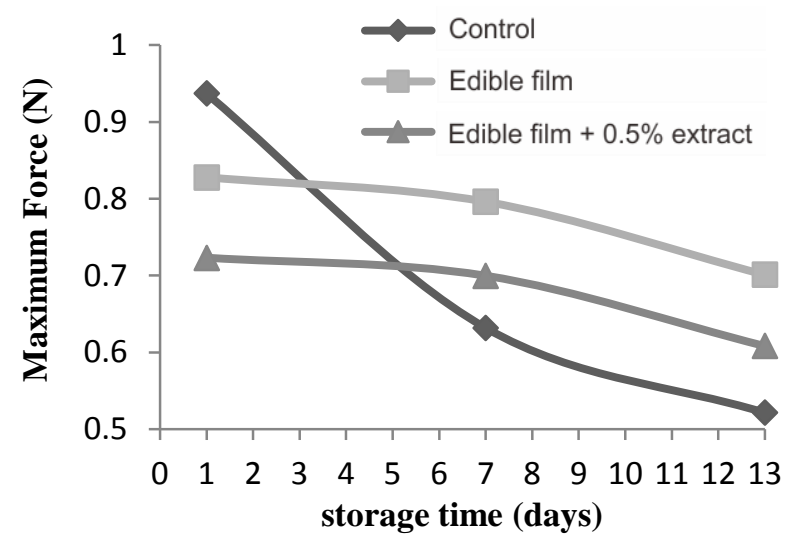

Figure 4. Graph of Red Grape Grape Texture Test result during storage.

The value of red grape texture test results showed in Figure 4 shows that edible film coating on red grape can reduce red grape texture decrease. This is supported by research of Sari et al. (2015), which informed that the texture of strawberries decreased during storage and hardness value of strawberries without coating more quickly decreased compared with the coated strawberries. The reduction of red grape texture during storage is caused by the loss of water content in the cells resulting from the respiration and transpiration of red grapes so that the water-deficient cells become softer and weaker. Fruit coatings using edible film can suppress high transpiration and respiration in order to inhibit the loss of water content in the fruit tissue (Sari et al., 2015).

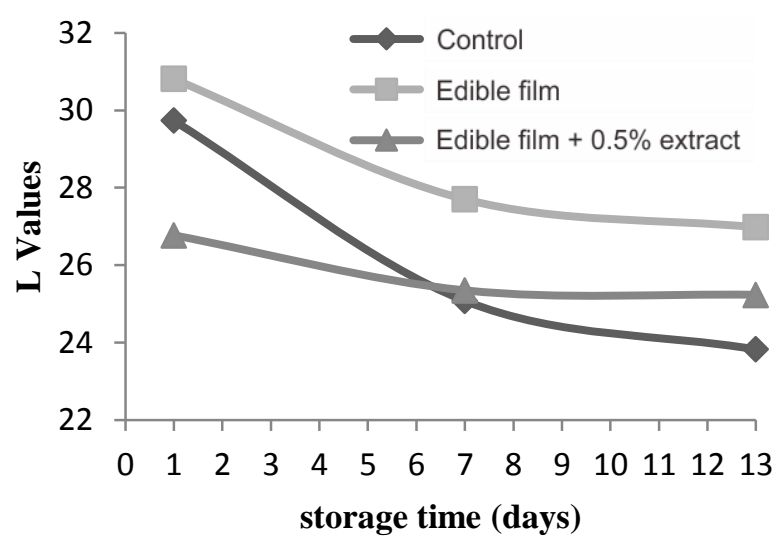

Figure 5. Graph of test result of L Values of Red Grape during storage.

Red grape storage period is determined based on texture softening by $50 \%$ using the equation of the line. Red grape controls were subjected to $50 \%$ texture softening on day 13 , red grape coated with edible films without extract additions were able to retain $50 \%$ of the texture for up to 41 days, and in red grape coated with edible film with the addition of soursop leaf extract subjected to as much texture softening $50 \%$ on day 40 .

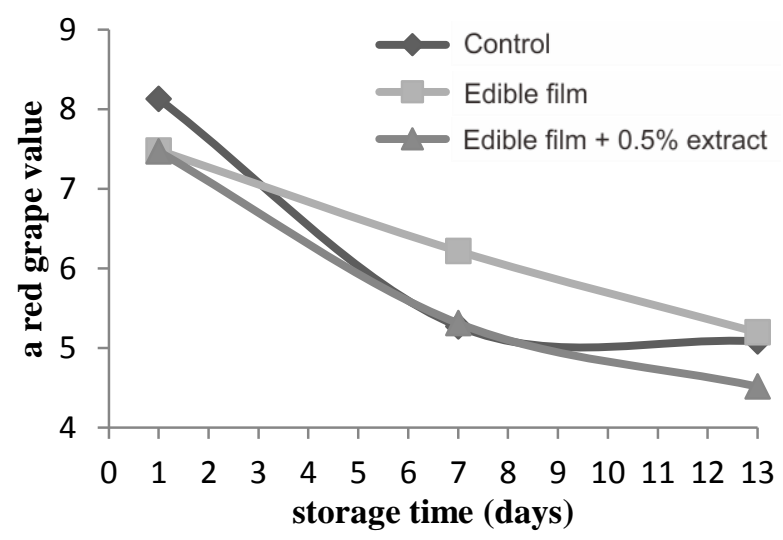

Figure 6. Graph of test result of a Red Grape Value during storage.

Observations of discoloration on red grape samples were performed using a chromameter tool. Interpretation of data to color is translated through the scale $\mathrm{L} * \mathrm{a} * \mathrm{~b}$. The value of $\mathrm{L}$ denotes the brightness of the red grape, a scale represents the color red-yellow, and scale b denotes a blue yellow color (Kismaryanti, 2007). 


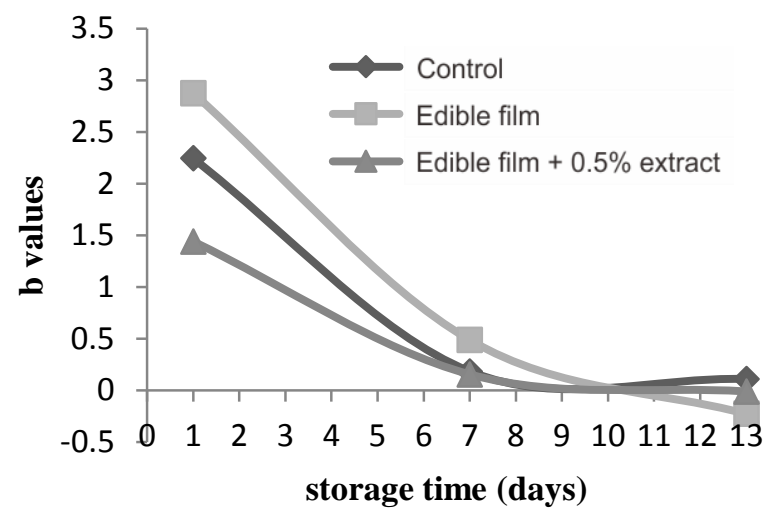

Figure 7. Graph of test result of B Value of Red Grape during storage.

Based on these data, the longer time red grape storage, the value of $\mathrm{L}, \mathbf{a}$ and $\mathbf{b}$ red grape decreased. The observations of the color test showed that the treatment of red grape coating with edible film without the addition of extract and with the addition of extract had not been able to inhibit the decrease of $\mathrm{L}$, $\mathrm{a}$, and $\mathrm{b}$ values during storage.

\section{CONCLUSION}

Based on the research that has been done, it can be concluded that the best edible film are from the addition of soursop leaves extract $0.5 \%$ (w/w total). The addition of soursop leaf extract of $0.5 \%$ (w/w total) to edible film of ganyong starch and Aloe vera L. can affect the physical properties of edible film, i.e. increasing film thickness from 0,03 to $0,08 \mathrm{~mm}$, decreasing tensile strength of 11,89 to $8,42 \mathrm{MPa}$, decreased elongation value from 12,71 to $11,03 \%$, Young Modulus decreased from 0,935 to $0,764 \mathrm{MPa}$, and decreased vapor transmission rate from 7,45 to $6,55 \mathrm{~g} / \mathrm{m}^{2}$.hour. Red grape storage time is elongated in terms of $50 \%$ shrinkage and $50 \%$ texture damage.

\section{REFERENCES}

Afriyah, Y., Putri, Widya Dwi R. \& Wijayanti, Sudarma D.. 2015. Penambahan Aloe vera L. Dengan Tepung Sukun (Artocarpus communis) dan Ganyong (Canna edulis Ker.) Terhadap Karakteristik Edible film. Jurnal Pangan dan Agroindustri, 3(4): 1313-1324.

Donhowe, G. \& Fennema, O.. 1994. Edible Film And Coating: Characteristic, Formation, Definitions And Testing Methods. In Krochta, J.M., Baldwin, E.A. and Nisperos-Carriedo, M.O. (eds.). Edible Coating and Film to Improve Food Quality. Technomic Publ. Co. Inc. Lancaster, Pennsylvania. p. 378.

Edeoga, H.O \& A. Gomina. 2000. Nutritional Values Of Some Nonconventional Leafy Vegetables Of Nigeria, J.Econ, Taxon, Bot, 24 dalam Febriani, Diana., et al. 2015. Karakterisasi Simplisia dan Ekstrak Etanol Daun Sirsak (Annona Muricata Linn). Prosiding Penelitian SpeSIA Unisba, p. 457- 480.
Harikedua, S.D.. 2012. Penhambatan Oksidasi Lipida Ikan Tuna oleh Air Jahe Selama Penyimpanan Dingin. Jurnal Perikanan dan Kelautan Tropis, VIII-1.

Irianto, H.E., Darmawan, M. \& Mindarwati, E., 2006. Pembuatan Edible Film Dari Komposit Karaginan, Tepung Tapioka dan Lilin Lebah (Beeswax). J. Penel. Perik. Indonesia, 1 (2): 93101.

Kismaryanti, Andiny. 2007. Aplikasi Gel Lidah Buaya (Aloe vera L.) Sebagai Edible Coating Pada Pengawetan Tomat (Lycopersicon esculentum Mill.). Thesis: Fakultas Teknologi Pertanian, Institut Pertanian Bogor.

Krochta, J.M \& Johnston, C.M.. 1997. Edible And BioDegradable Polymer Films. J. Food Technology, 51 (2): 6174.

Kusumawati, D., H., \& W. D. R. Putri. 2013. Karakteristik Fisik dan Kimia Edible film Pati Jagung Yang Diinkorporasi Dengan Perasan Temu Hitam. Jurnal Pangan dan Agroindustri, 1 (1): 90-100.

Lathifa, Hafidzatul. 2013. Pengeruh Jenis Pati sebagai Bahan Dasar Edible Coating dan Suhu Penyimpanan terhadap Kualitas Buah Tomat (Lycopersicon esculentum Mill.). Thesis: Fakultas Sains dan Teknologi, Universitas Islam Negeri Maulana Malik Ibrahim.

Murdianto, W.. 2005. Sifat Fisik dan Mekanik Edible film Ekstrak Daun Janggelan. Universitas Gajah Mada Yogyakarta.

Nahwi, Naufal Fadli. 2016. Analisis Pengaruh Penambahan Plasticizer Gliserol Pada Karakteristik Edible Film dari Pari Kulit Pisang Raja, Tongkol Jagung, dan Bonggol Enceng Gondok. Thesis: Fakultas Sains dan Teknologi, UIN Maulana Malik Ibrahim Malang.

Rivai, H., Ernita Widiya S, \& Rusdi. 2013. Pengaruh Perbandingan Pelarut Etanol-Air Terhadap Kadar Senyawa Fenolat Total dan Daya Antioksidan dari Ekstrak Daun Sirsak (Annona muricata L.). Jurnal Sains dan Teknologi Farmasi, 18 (1): 35-42.

Santoso, Budi, Filli Pratama, Basumi Hamzah \& Rindit Pambayun, 2011. Pengembangan Edible film dengan Menggunakan Pati Ganyong Termodifikasi Ikatan Silang. Jurnal Teknol dan Industri Pangan, XXII (2): 105-109.

Sari, R.P., Wulandari, Septia T., Wardhani \& Dyah H.. 2013. Pengaruh Penambahan Ekstrak Bawang Putih (Allium sativum) terhadap Karakteristik Edible film Pati Ganyong (Canna edulis Kerr.). Jurnal Teknologi Kimia dan Industri, 2 (3): 82-87.

Sari, Rita N., Dwi Dian Novita \& Cicih Sugianti. 2015. Pengaruh Konsentrasi Tepung Karagenan dan Gliserol Sebagai Edible Coating Terhadap Perubahan Mutu Buah Stroberi (Fragaria X Ananassa) Selama Penyimpanan. Jurnal Teknik Pertanian Lampung, 4 (4): 305-314.

Sulistiana, Evi Erizha \& Widya Dwi Rukmi Putri. 2015. Komparasi Penggunaan Tepung Ganyong dan Tepung Sukun Terhadap Karakteristik Edible film Kulit Jeruk Bali. Jurnal Pangan dan Agroindustri, 3 (4): 1325-1336.

Suryadi, Meliani Octavia. 2011. Aplikasi Pati Ganyong dan Gliserol Sebagai Edible Coating Pada Stroberi (Fragaria ananasa). Thesis: Fakultas Teknologi Industri, Universitas Pelita Harapan.

Suteja, Kadek P., Rita, Wiwik S. \& Gunawan, I.W.G.. 2016. Identifikasi dan Uji Aktivitas Senyawa Flavonoid dari Ekstrak Daun Trembesi (Albizia saman (Jacq.) Merr) Sebagai Antibakteri Escherichia coli. Jurnal Kimia, 10: 141-148.

Suwarto, Agus. 2010. 9 Buah dan Sayur Sakti Tangkal Penyakit. Yogyakarta: Liberplus. 
THIS PAGE INTENTIONALLY LEFT BLANK 